\title{
Sixty years in the making: the history of Eikestadnuus $(1950$ - 2009)
}

\author{
Francois P. Verster
}

\begin{abstract}
Community papers perform a unique role by informing, educating and rallying their demarcated piece of society,as well as reflecting the opinion of such communities and shaping them. In this respect Eikestadnuus (in Stellenbosch, Western Cape Province, South Africa) is no different to any other weekly newspaper. Yet, it has its own story. A belated birth, maturity after 30 years (when it came under new ownership) and now, with 60 years behind it, it is still going from strength to strength. Eikestadnuus, as the news organ of a university town, and with different cultures, has to cater for a broad spectrum of readers. It had to adapt to opposing political systems, interpreting the nature of democracy differently as well and shifting ethical and practical priorities to the dictates of 14 editors to date. In this paper the above is discussed and Eikestadnuus is measured against the universal blueprint of a fully functional community newspaper.
\end{abstract}

\section{Key words}

Boland, community, democracy, editorial styles, Eikestadnuus, language, local, market, printing, Stellenbosch Gazette.

\section{The community newspaper: raison d'être}

Small media can be divided into two groups: community media that is non-profit and independent media, which is small and commercial (Meissenheimer, 2006:31). Eikestadnuus falls in the latter category and for the purposes of this article it will be referred to as a community paper.

According to the American veteran journalist B.M. Kennedy, a community paper needs rapport with the community above everything else - every individual needs not only to identify with the paper, but if possible, be referred to in the paper. Mention of births, marriages and deaths are a given, but activities and achievements that may not be reported in mainstream papers and magazines are tailor made for community papers (Kennedy, 1974: $15-18$ ).

Riaan Gerber, thirteenth editor of Eikestadnuus, states that every inhabitant of a town should be referred to in a community paper and that the community in totality should be reached: 'Every member of a community is a potential source of news. Every resident has an opinion regarding local affairs.' He added that 'a town is made by its citizens. Not the other way round.' According to Gerber this axiom has become the mantra of the Eikestadnuus (Gerber, 2000: 8). 


\section{Historical background: are we there yet?}

By the turn of the previous century, about half a dozen local newspapers had existed in the area known as the Boland, but not in the town of Stellenbosch which was founded in 1679, making it the second oldest town in South Africa (Bouman 1929: 11; Muller Ed., 1977: 41). Since the first Afrikaans newspaper, Die Afrikaanse Patriot, was published in 1876 in the neighbouring town of Paarl (Nienaber, 1974: np), this seems all the more unusual.

To understand this state of affairs, one needs to study the demographics of the immediate vicinity, the Zeitgeist of successive historical periods and the history of Stellenbosch as well as that of the country in general. What may appear strange to one living in the $21^{\text {st }}$ century was taken for granted in past times. One factor seems to be political - the white quarter of the community was still more divided than appears to be at present, and therefore the language issue would come up when creating a "spokesperson" for the larger community - even today it remains a talking point (Brown, 2008: 2). Secondly, economical reasons may have weighed heavily after two world wars and the Great Depression which impoverished people of all communities (Steyn, 2002: 11).

By the beginning of the 1950's the global and local economic situation improved, and affluence was showing in the business sector - sponsors were available and companies were looking for ways to promote their interests (Boodskappe van, 1950: 1). In the case of community papers, the very localism of the market is both detrimental and advantageous - while the distribution area is limited, local businesses and other institutions realise the advertising potential of such a publication (Frost, 2009).

This was evident with the first publication of Eikestadnuus on 24 March 1950. That said, one can speculate that the main reason for the late start of Eikestadnuus was competition. The community papers Overberg Venster, Worcester Standard, Hermanus Times, District Mail and Paarl Post were all distributed in the vicinity of Stellenbosch and even competed with each other (as they still do) to include this area before Eikestadnuus appeared on the scene. (News24.com/regionals: 1-3). The fact remains, few people can afford to buy more than one community newspaper (Lubinga, 2001: 24). Moreover, mainstream papers like Die Burger and The Cape Times have been readily available because of a good infrastructure linking Cape Town with Stellenbosch. Due to the the fact that Die Burger and its publishing company, Nasionale Pers (Naspers since 1998), was founded in 1915 in Stellenbosch, with a strong link between the paper, the company and the white Afrikaner community as well as their political party, the Nationalist Party (Muller, 1990: 50), one can conclude that the necessity for a community paper was not of primary concern as Die Burger would serve the interests of the community and the party.

\section{Stellenbosch at last: Eikestadnuus arrives}

After almost four decades, however, a local community paper was founded. Eikestadnuus was the brainchild of Schalk van der Merwe, administrative manager of the Stellenbosch publishing company Pro Ecclesia Printers, and a colleague of Burton, factory manager at the printing press. Pro Ecclesia later became part of the Rembrandt Group (Van der Walt, Prins \& Scholtz, 1992: 332), which explains the initial involvement of this institution with Eikestadnuus. The municipality of Stellenbosch was 110 years old in 1950 (Mertens 1971: np) and Van der Merwe and Burton must be congratulated for at last bringing 
the journalistic profession to the town where the then already mighty, although only national, Naspers was founded. It was here that a Department of Journalism would eventually be established with the aid of Naspers. Journalism students would serve internships and gain experience at Eikestadnuus (Moolman \& Gerber, 1986: 1).

The paper was welcomed with fanfare and high expectations - messages from local luminaries such as the mayor Louis Hofmeyr, rector of the University of Stellenbosch, Bobby Wilcocks and AJM Fourie, chairman of the Stellenbosch Chamber of Commerce, were splashed over the front page (Boodskappe van, 1950: 1). Significantly almost a third of this page was allocated to an advertisement for Rembrandt, a leader of commerce and future owner of the paper (Elke sigaret, 1950: 1). At the same time the general public was awarded space in the paper, as would be expected from a community paper, like a certain Mrs. Nolte who was congratulated for her first place at the Rosebank Show where she achieved full marks for a knitted bedspread (Persoonlik, 1950: 2).

In the first edition the editor, Basie Botha, stated that this paper aspired to fulfil a need no other publication could and to maintain standards that would be worthy of Stellenbosch, "Eikestad" (Town of Oaks), as this town is widely known, and from which the paper subsequently took its name. The paper would be bilingual and non-political, and appeal to readers to consider it their paper, to identify with it, irrespective of which of the two "volksdele" white nation: with the understanding of Afrikaner or English descendants) they belonged to. (Uiteindelik ons, 1950: 4). In other words the two white language groups seem to have been the only market the paper catered for. This editorial policy would gradually change, with people from other racial groups becoming staff members and regularly featuring in articles and photographs (as an example the story "Bejaardes staan ure tou", 2000: 2). In being bilingual the Eikestadnuus continued with a tradition started on 16 August 1800, when the first newspaper on South African soil, The Cape Town Gazette and African Advertiser was published (Potgieter, Ed., 1973: 187).

\section{Getting down to grips: finding an own identity}

Eikestadnuus initially consisted of eight pages, with the editorial in both English and Afrikaans, but from the second issue editorials appeared in Afrikaans or English alternatively (Stellenbosch vir, The rains came, 1950: 4).

\section{Language}

The language issue was raised in the letters column four years after inception of the paper, when an English speaker complained (ironically in Afrikaans) about the excess of Afrikaans articles (Ontaard ons?, 1954: 5), while this was guaranteed not to occur in the first issue of Eikestadnuus. The response from the editor was that Stellenbosch is "traditionally Afrikaans," that 80 percent of the inhabitants spoke Afrikaans, which meant that Afrikaans was spoken twice as much as English, and he could not be held responsible for the fact that English speakers could not read Afrikaans, while Afrikaans-speaking readers could understand English. Moreover, he reasoned, articles and letters are published in the language in which they had been written (Eikestadnuus tradisioneel, 1954: 5). Afrikaans readers seem not to have been worried about English per se, but did complain about the use of slang words in Afrikaans pieces (Schoonees, 1952: 4). 


\section{News focus}

Contents consist mainly of reports on community and cultural affairs, and as a university town educational and sports news featured prominently right from the start. Reports on infrastructure, sanitation and health issues were balanced with personal news, like visitors to the town, appointments (mainly regarding the university) and the accomplishments of local people enjoyed precedence to news from other regions and abroad. Prominent citizens regularly made the headlines, such as rugby legend Danie Craven (920 seuns, 1973: 1), and eminent historian H.B. Thom (Die nuwe, 1954: 3), but most articles are about lesser known Stellenbosch residents, reflecting the everyday life of the town and environs.

\section{Columns/opinion}

Early columns were "Wat die papegaai sê," a personalised account of localised gossip (1950: 3; 1953: 5), "Profetiese woorde," which were theological essays and "Oom Japie vertel," a series of historical narratives by one of the senior citizens of Stellenbosch (1950: 3). Column writing, however, never really featured prominently in Eikestadnuus, for few columns were published and lasted long, although correspondents eventually were used regularly (Retief, 2009: 1). Religious and gender issues surfaced early on, as an article on a survey conducted by a theological student reveals - apparently women were more conservative and religious than men (Vroue konserwatiewer, 1951: 2). The matter of fact way in which these findings were revealed was indicative of a time when feminism and sexism were practically unknown.

\section{Getting the work done: the inner workings}

Initially the editor's office was conveniently near to Pro Ecclesia (printers) and Rembrandt (owners) in 89 Bird Street (Slotegraaf, 2009). In the 1960s Eikestadnuus moved to its current location, the Laetitia Building in Alexander Street (Botha, 2000: 10) adjacent to the town square, Die Braak, where the townspeople, for many generations since the period of Dutch occupation in the $17^{\text {th }}$ century, and long before the arrival of Eikestadnuus, went to buy at the market and to exchange news (Bouman, 1929: 13).

To date Eikestadnuus has had 14 editors. Basie Botha was the first, followed by Marie Theron and "Mrs Schalk van der Merwe" as co-editors. Another lady, H. de Vos succeeded them, after which Ted Ellis, Piet Jordaan, Johanna van Graan and W.A. de Klerk followed. Then came Nico Uys and Sophie Hendriks, Tinka Botha, Louis Wepener (Botha, 1970: 1), Riaan Gerber and Elsabé Retief (Slotegraaf, Maart 2009).

According to Tinka Botha the staff - not only the editorial staff - has always been small. When she took over in 1967 she was half the staff, with one other woman, Chrissie Snyders who was in charge of bookkeeping and advertisements (Botha, 2000: 10). Today the personnel consist of an editor, four reporters, an intern and 14 administrative staff (Retief, 2009: 1). Like Potchefstroom Herald, Eikestadnuus "exploits" the availability of a cheap source of labour: journalism students from the nearby university (Van der Walt et al., 1992: 332). 
As far as financing is concerned, Die Landman was the original publisher-owner of Eikestadnuus for almost two decades. On 12 February 1969 Eikestadnuus Limited took over this responsibility to be succeeded by Boland Koerante on 25 May 2007 until the present (Verster, 2008: 2). In 1984 Eikestadnuus became a component of Nasionale Pers (Naspers since 1998), the dominant media company in South Africa when Naspers obtained 50 percent of the shares, as well as control over the paper. The rest of the shareholders are Rembrandt, Oude Meester, Gilbeys (now United Distillers \& Vintners) and Stellenbosch Farmers' Winery (now Distell), all local companies (Van der Walt et al., 1992: 329, Naspers Archives AL17, 9/6/4, Naudé, 1984: 1).

After six decades Eikestadnuus has progressed from being a medium in which local businesses can promote their products, to a means for a major media company to broaden its sources of income. Many newspaper corporations have chosen this route to compensate for the decrease in income due to changing consumer patterns caused by the advent of television (Lubinga, 2001: 20). In the case of Naspers, being a shareholder in all sectors of the media nationally (Voornoteringsverslag, 1994: 1-3; Wikipedia.org/wiki/Naspers: 1) - including television - was the next step in securing a grip on yet another slot in the market.

It has become unpractical and uneconomical for every rural newspaper to have its own printer (Frost, 2009). This is evident when tracing the history of Eikestadnuus's printers - in June 1969 Pro Ecclesia, the original printers moved to premises in Observatory, then to Epping in January 1972, where printing was eventually taken over by Printpak from June 1973. In April 1983 Die Paarlse Drukpers was contracted to print Eikestadnuus which lowered production costs, because of the proximity of Paarl to Stellenbosch. Paarl Post Media, the modern equivalent of the old Paarl printing works is presently charged with this part of production (Verster, 2008: 5).

\section{Advertising/revenue}

Newspapers cannot survive from subscription alone, with advertisements being the main source of income. The regular weekly real estate advertising supplement demonstrates that real estate plays an important part in Stellenbosch and environs. Local businesses and agricultural produce, with the wine and spirits industry prominent, make up the remainder of the advertising focus (Van Aardt, 2009: 19).

On 3 November 1998 Eikestadnuus Limited launched Stellenbosch Gazette, a gratis newspaper (Dinsdae is Gazette-dag, 2000: 16), which competes with others such as Bolander (since 2007), published by the opposition, such as Independent Newspapers (Frost, 2009). This initiative is 'based on the confidence Eikestadnuus has in the future of Stellenbosch as a town' and because this paper will be distributed to every home within the municipal area of Stellenbosch, new markets will be opened to local advertisers, according to the editor at the time. The initial distribution figures were 13700 copies, which are issued on Tuesdays, with Eikestadnuus traditionally going out on Fridays. The Gazette is distributed to the so-called satellite towns of Stellenbosch, such as Pniël, Kylemore and Jamestown (Dinsdae is Gazette-dag, 2000: $16)$.

\section{The digital era}


In 1997 Eikestadnuus went online by launching a website (stellenboschvillage.com) to complement Eikestadnuus, and, one year later, Stellenbosch Gazette, which proved to be popular, as the website is visited by readers preferring the electronic option of reading headlines, the weather or advertisements. Monthly hits totalled 100000 within three years of conception (Website complements the Eikestadnuus package, 2000: 2). Like the Stellenbosch Gazette, this extension of the service and reach of Eikestadnuus is a strategy to contest the influence of competing newspapers as well as electronic media - a case of "if you can't beat them join them." In this way Eikestadnuus widened its income and reader base (Gerber, 2009: 1). The Gazette is distributed to 17000 homes and it is estimated that Eikestadnuus is read by 40 000 people (Retief, 2009: 1).

\section{At the heart of it all: the community}

Taking the focus of community media into account, namely serving a community, Eikestadnuus has a good record (Malan \& Retief, 2000: 14; Nowers, 2000: 6; Snyman, 2000: 6). Despite all appearances community involvement across racial lines was evident since the first year of the paper's existence. On 14 July 1950 an article titled "Die lewe in Kaya Mandi" reports on the history of the "location" during a time when most white readers, and as such most readers of Eikestadnuus, probably did not want to know about the hardships of black people (1950: 1). According to the current editor, Elsabé Retief, the paper tries to be involved while maintaining independence - this balance has proven to be difficult to keep, while acceptance by the community is essential as well as credibility as a fair and honest arbitrator (Retief, 2009: 3).

The effort to promote awareness and contact between Eikestadnuus and the public is manifest throughout the existence of the paper, as seen in the article "Kom ons vat hande nog vaster" on 12 September 1986 (1986: 1) and "Putting the community's interest first" on 7 April 2000 (Malan \& Retief, 2000: 14). Eventually practical involvement in education, such as the KIK-programme (Koerant in die Klaskamer newspaper in the classroom) and reporting on activities of schools from all sectors of the community has raised the popularity of Eikestadnuus among educators and learners alike (Eikestadnuus se, 2000: 7). Besides projects with schools (including sports promotions) businesses are engaged as sponsors. Recently the Trammakassi-festival was initiated to commemorate the abolition of slavery (Price, 2009: 1).

A newspaper in post-apartheid South Africa's liberal democracy, and from a social responsibility as well as development media theoretical perspective, is in a position to contribute to exemplify democratic values - teaching readers from different backgrounds and even opposing perspectives to respect one another's views and to apply greater objectivity. Due to the separation of residential areas, schools and even the workplace to some extent under apartheid, such exposure had been severely curtailed. Therefore a community newspaper has an even bigger role to play to "normalise" segregated sectors of a community. A public forum for everyone who can send in a letter to the editor is now available and this debate is ongoing and growing (Kalazana, 2000: 14).

Besides being a community paper per se, Eikestadnuus has the basic responsibilities of any newspaperto protect democracy by keeping the public informed and being a watchdog: the so-called "Fourth Estate", especially in terms of local government. Local papers play an important role in protecting the 
cultural and natural heritage of a community. An example of this was preventing the demolition of Lubbe Huis, now Schreuder Huis, and part of the town's museum complex (Botha, 2000: 10).

A community newspaper also has to be aware of its role as educator. Despite its comparatively limited reach, it acts "... as a window through which the rest of the world can view a society as well as a mirror through which society can examine itself" (Lubinga, 2001: 1). Having entered the medium of websites and electronic advertising, Eikestadnuus has linked Stellenbosch to the rest of the global village.

\section{In perspective: a newspaper with a decent future has a respectable history}

The history of a newspaper mirrors the beliefs, perspectives and assumptions with which it views events, etc. in its time, as well as the interpretation and commentaries of how it presents all of this to its readers (Zaaiman, 1983: np). According to this norm Eikestadnuus has as good a record as any paper, judging by the general standard of "objective reporting" these past 60 years. According to Francois Groepe, executive manager of Media24 (the printing component of Napers), Eikestadnuus has established itself in several roles in the community it serves; as newsmaker, activist, peacemaker, mobliser and conversationalist. This, he claims, is not easy in a diverse community with a wide range of interests. After six decades readers have come to accept Eikestadnuus in these manifold roles, while the media profession also recognises the quality of this newspaper's efforts. Eikestadnuus has won several accolades over the years, such as the Hultzer trophy for best community paper in the country (Groepe, 2009: 2).

The paper has, from the outset, maintained the high standards set out in the first edition (Boodskappe van, 1950: 1) and managed to win several prizes over the past 60 years (Van der Walt et al., 1992: 332; Foto van, 2000d: 12). While relatively few references to racism are to be found in the almost 3000 editions so far, the newspaper has, as promised in the first edition, for the most part avoided taking a political stance. It prefers to be "event-driven rather that policy-driven" (Retief, 2009: 1).

Every person is born in a group with its own moral constraints which determine the future behaviour of such individuals (Barnard, 1941: 21). Perhaps the most difficult mission for any newspaper in a multicultural society is to help shape a common ethos. In this every newspaper and every journalist has a moral obligaton to uphold.

\section{References}

Barnard, D.F. 1941. Die pers en die volksmoraal. (The press and the ethics of the people). Unpublished M.A. thesis. University of Stellenbosch, South Africa.

Bejaardes staan ure tou. (Elderly waiting in queues for hours). Eikestadnuus, 2000-03-3: 2.

Botha, B. 1970. Eikestadnuus 20 jaar. (Eikestadnuus 20 years). Eikestadnuus. 1970-03-20: 1.

Botha, T. 2000. Vroue het in dié tydperk septer geswaai. (Women reigned supreme at this time). Eikestadnuus. 2000-04-7: 10. 
Bouman, A.C. 1929. 'n Besoek aan Stellenbosch. (A visit to Stellenbosch). In: Stellenbosch 1679 - 1929. Die Dorpsraad van Stellenbosch:. 11, 13. Stellenbosch: Hortors.

Boycott of press, 1951. Eikestadnuus. 1951-04-21: 1.

Brown, B.B. 2008. Translation please. Bolander, 2008-04-05: 2.

Boodskappe van Stellenbosch. (Messages from Stellenbosch). 1950. Eikestadnuus. 1950-03-24: 1.

Die nuwe rektor - 'n praktiese idealis. (The new rector - a practical realist). 1954. Eikestadnuus. 195403-05: 3.

Dinsdae is Gazette-dag. (Tuesdays are Gazette days). 2000. Eikestadnuus. 2000-04-07: 16.

Eikestadnuus se KIK-program 'n wenner. (Eikestadnuus's KIKS program a winner). Eikestadnuus 200004-07: 7.

Eikestadnuus tradisioneel Afrikaans. (Eikestadnuus traditionally Afrikaans). Eikestadnuus. 1954-02-08: 4.

Elke sigaret 'n meesterstuk. (Each cigarette a masterpiece). Eikestadnuus. 1950-03-24: 1.

Foto van die jaar was spanwerk. (Photograph of the year due to teamwork). Eikestadnuus, 2000-04-07: 12.

Frost, C. 2009. Personal interview with editor of Bolander. 2009-03-13. Stellenbosch.

Gerber, R. 2000. Inwoners is Eikestadnuus se belangrikste aandeelhouers. (Residents are the most important shareholders of Eikestadnuus). 2000-04-07: 8.

Gerber, R. 2009. Personal e-mail from former editor of Eikestadnuus. Received: 2009-03-18.

Groepe, F. In diens van ons lesers (At the service of our readers). Eikestadnuus. Special edition. 2009-0529:.2.

Kalazana, W. 2000. Message from the mayor. Eikestadnuus, 2000-04-07: 14.

Kennedy, B.M. 1974. Community journalism, a way of life. Ames, United States of America: The Iowa State University Press.

Kom ons vat hande nog vaster. (Let us take hands even more firmly). Eikestadnuus, 1986-09-12: 1. 


\section{GMJ - AE 2010 Vol 4 (1)}

Lubinga, E.N. 2001. A comparative study of the factors affecting the growth/ development of the rural community newspapers the Zoutpansberger and Mirror, Northern Province. Unpublished MA thesis, University of Stellenbosch, South Africa.

Malan, H. \& Retief, E. 2000. Putting the community’s interest first. Eikestadnuus, 2000-04-07:14.

Meissenheimer, H. 2006. How much to say or do? An exploration from a public journalism perspective on the community involvement of the West Coast commercial community newspaper Weslander. Unpublished M.A. thesis. University of Stellenbosch, South Africa.

Mertens, A. 1971. Stellenbosch. Cape Town: Tafelberg.

Moolman, M. 1986. Letter to R. Gerber. Naspers Archives AL17. 9/6/4. 1986-06-13: 1.

Muller, C.F.J. (Ed.). 1977. 500 jaar geskiedenis. (500 years history). Pretoria: Academica.

Muller, C.F.J. 1990. Sonop in die suide: geboorte en groei van die Nasionale Pers 1915 - 1948. (Sunrise in the south: birth and growth of the National Press 1915 - 1948). Cape Town: Tafelberg.

Naudé, C. 1984. Progress report. Naspers Archives AL17 9/6/4. 1984-04-30: 1.

News.24.com.regional papers. Retrieved 2009-03-23 from World Wide Web: http://www.news24.com/Regional.

Nienaber, G.S. 1974. Introduction. In Die Afrikaanse Patriot: 'n faksimilee-weergawe van die eerste jaargang 1876. (Die Afrikaanse Patriot: a facscimilee of the first year's edition 1876). Die PatriotVereniging. Cape Town: Tafelberg.

Nowers, S. 2000. Eikestadnuus is 'n vriend. (Eikestadnuus is a friend). Eikestadnuus, 2000-04-7:6.

Ontaard ons blad in Afrikaans? (Is our paper becoming Afrikaaans?). Eikestadnuus. 1954-02-8: 5

Oom Japie vertel. (Uncle Japie recounts). Eikestadnuus. 1950-05-19: 3

Paarl Post - 123 years of service to the Valley. Eikestadnuus. 2000-04-07: 5.

Persoonlik. 1950. (Personal). Eikestadnuus. 1950-03-24: 1.

Potgieter, D.J. Ed. Standard Encyclopedia of South Africa. Vol.8. Nasou: 1973.

Price, I. 2009. Personal e-mail from senior journalist of Eikestadnuus. Received: 2009-03-27: 1. 


\section{GMJ - AE 2010 Vol 4 (1)}

Retief, E. Betrokke, dog onafhanklik (involved, yet independent). Eikestadnuus. Special edition. 29 May 2009-05-29: 3 .

Retief, E. Personal e-mail from editor of Eikestadnuus. Received: 2009-03-27: 1.

Schoonees, P.C. 1952. Letter to the editor, untitled. Eikestadnuus. 1952-05-23:. 4.

Slotegraaf, B. 2009. Personal interview with former employee of Rembrandt conducted on 2009-03-25.

Snyman, L. 2000. Eikestadnuus shapes opinion. Eikestadnuus. 7 April 2000-04-07: 6.

Stellenbosch vir die Stellenbossers. (Stellenbosch for residents of Stellenbosch). Eikestadnuus. 1950-0324: 4.

Steyn, J.C. 2002. Penvegter, Piet Cillié van Die Burger. (Penfighter, Piet Cillié of Die Burger). Cape Town: Tafelberg.

The rains came.. Eikestadnuus, 1950-03-31: 4.

Uiteindelik ons eie! (Ours at last!). Eikestadnuus. 1950-03-24: 4.

Van Aardt, P. 2009. Die prys van Paradyskloof. (The price of Paradyskloof). Eikestadnuus, 2009-03-27: 19.

Van der Walt, W., Prins, J.D. \& Scholtz, J.J.J. Streek- en tuiskoerante (Regional and local papers).In: Beukes, W. Ed. 1992. Oor grense heen. (Across borders). Cape Town: Nasionale Boekhandel..

Verster, F.P. 2008. Historical notes on Eikestadnuus. Unpublished memorandum. Naspers Argief. Unnumbered. 2008-12-22: 5.

Voornoteringsverslag: 'n nuwe mylpaal vir die Nasonale Pers. (Pre-listing report: a new milestone for the National Press). 1994.

Vroue konserwatiewer as mans. (Women are more conservative than men). Eikestadnuus. 1951-01-19: 2.

Wat die papegaai sê. (What the parrot say). 1950. Eikestadnuus. 1950-03-24: 3.

Wat die papegaai sê. (What the parrot say). 1953. Eikestadnuus. 1953-07-31: 5.

Website complements the Eikestadnuus package. Eikestadnuus, 2000-04-07: 2. 


\section{GMJ - AE 2010 Vol 4 (1)}

Wikipedia, 2009. Naspers. Retrieved 2009-03-26 from the World Wide Web:

http://en.wikipedia.org/wiki/Naspers.

Zaaiman, S.F. 1983 Die Volksblad (1925 - 1934), unpublished historical account, Bloemfontein.

920 seuns trek saam op 'vader' se voorstoep. (920 boys gather on 'father's' porch). Eikestadnuus. 197306-26: 1. 